\title{
Türkiye’de Tarımsal Kalkınma Kooperatiflerinde Yöneticilerin Özellikleri
}

\author{
Ahmet ŞAH N ${ }^{1}$, Bülent M RAN ${ }^{2}$, Murat CANKURT ${ }^{3}$, Cihat GÜNDEN ${ }^{2}$, Cevahir KAYNAKÇI ${ }^{1}$ \\ ${ }^{1}$ Kahramanmaraş Sütçü mam Üniversitesi, Ziraat Fakültesi Tarım Ekonomisi Böl., Kahramanmaraş \\ ${ }^{2}$ Ege Üniversitesi Ziraat Fakültesi Tarım Ekonomisi Böl., zmir \\ ${ }^{3}$ Adnan Menderes Üniversitesi Ziraat Fakültesi Tarım Eko. Böl., Aydın
}

Geliş (Received): 29.11.2013

Kabul (Accepted): 12.02.2015

\begin{abstract}
Özet: Bu çalısmanın amacı Türkiye'de Tarımsal Kalkınma Kooperatifi yöneticilerinin özelliklerini belirlemektir. Araştırmanın ana materyalini 84 kooperatif yöneticisi ile yapılan anketlerden elde edilen veriler oluşturmuştur. Çalışmanın Türkiye'yi temsil etmesi bakımından anketler 7 coğrafi bölgede yapılmıştır. Anketlerden elde edilen önemli bulgular; kooperatif yöneticilerinin erkek ağırlıklı olduğu, kooperatifçilik ilkelerinin, kooperatif yöneticileri tarafından bilinmediği ve bilinenlerin ise önemli bir kısmının uygulanmadığı yönündedir. Kooperatiflerin politik ve kişisel amaçlar güdülmeden yönetilmesi sürdürülebilir tarımsal örgütlenme açısından önemlidir.
\end{abstract}

Anahtar Kelimeler: Tarımsal Kalkınma Kooperatifi, Kooperatif Yöneticisi, Türkiye

\section{Characteristics of Agricultural Development Cooperatives Managers in Turkey}

Abstract: The aim of this study is to determine the characteristics of agricultural development cooperative managers in Turkey. The main material of this study is original data that obtained from the face to face interviews with 84 managers of agricultural cooperatives. Surveys have been made in 7 geographic regions in order to represent all of Turkey. Cooperative managers are mainly composed of male. Cooperative principles, not known by the managers of the cooperative and is an important part of the not applied. The management of cooperatives by political and personal purposes is important for sustainable agricultural organization.

Keywords: Agricultural Development Cooperatives, Cooperative Managers, Turkey

\section{G R Ş}

Tarımsal üretimin ekonomik, sosyal, teknik ve ekolojik bakımdan sürdürülebilir başarıya ulaşmasında en önemli faktörlerden birisi üreticilerin örgütlü olmasıdır. Üreticilerin örgütlenme başarısı ve/veya başarısızlığında öne çıkan unsur kooperatif yöneticileri olmaktadır. Türkiye'de tarımsal kooperatifler istenen hedefe henüz ulaşamamıştır. Tarımsal Kalkınma kooperatiflerinin başarı düzeyini etkileyen yönetici özelliklerinin ortaya konulması önem arz etmektedir.

Türkiye'de Gıda, Tarım ve Hayvancılık Bakanlığı, Çevre ve Şehircilik Bakanlığı ve Gümrük ve Ticaret Bakanlığı bünyesinde toplamda 25 kooperatif çeşidi bulunmaktadır. Türkiye'de toplam kooperatif sayısı 84199 ve ortak say1s1 8109210 'dur. Gida, Tarım ve Hayvancılık Bakanlığına bağlı 12990 birim ve 3890478 ortak, Çevre ve Şehircilik Bakanlığına Bağlı 57828 birim, 2215710 ortak, Gümrük ve Ticaret Bakanlığına bağlı 13381 birim ve 2003022 ortak bulunmaktadır. Gıda, Tarım ve Hayvancılık Bakanlığına bağlı olan Tarımsal Kalkınma Kooperatifi, Su Ürünleri Kooperatifi, Sulama Kooperatifi ve Pancar Ekicileri Kooperatifi 1163 nolu Genel Kooperatifler Kanununa tabii iken Tarımsal Kredi Kooperatifi 1581 nolu kanuna tabidir. Gıda, Tarım ve Hayvancılık Bakanlığına bağlı kooperatiflerin \%62.92'lik kısmını Tarımsal Kalkınma Kooperatifleri birimleri oluşturmaktadır. Bunu \%19.22 ile Sulama Kooperatifleri takip etmektedir. En az birimi olan kooperatif ise \%0.24 ile Pancar Ekicileri
Kooperatifi'dir (Anonim, 2013). En fazla birim kooperatif sayısına sahip olan Tarımsal Kalkınma Kooperatiflerinde başarının bir unsurunu ise önder veya lider özelliği taşıyan yöneticiler oluşturmaktadır. Başarı göstermiş kooperatif geçmişlerinde öne çıkan bu unsuru yöneticilerin özellikleri bakımından incelemek sürdürülebilir tarımsal örgütlenmeye katkı sağlayacaktır.

$\mathrm{Bu}$ çalışmanın amacı, başarılı kooperatiflerde başarıyı getiren; başarısız kooperatiflerde başarısızlığa yol açabilen yöneticilerin tutum, davranış ve özelliklerini, kazanılmış deneyimler olarak belirleyip, bunların Türkiye'deki kooperatifçilik çabalarının sürekli bir başarıya ulaşması için kullanılması hedeflenmektedir. Özetle Kooperatif işletmelerin başarısı; kooperatif yöneticileri açsından ele alınacaktır. $\mathrm{Bu}$ çerçevede: Kooperatif yöneticilerinin kooperatiflerde başarıyı belirleyen faktörler üzerindeki görüşleri ve bunların etkilerinin ortaya konulması amaçlanmıştır.

Tarımsal kooperatifçilik konusunda literatür oldukça geniştir. Bir kısım çalışmalar kooperatif üyelerinin ekonomik analizini esas alırken (Yercan, 1996; Acar ve Yıldırım 2000; Dedeoğlu ve Yıldırım, 2006), bir bölümü ise kooperatiflerin sosyo ekonomik faaliyetlerini incelemektedir (Yıldırım ve Acar, 1999; Karlı ve Çelik, 2003; Özdemir, 2005; Ünal ve Yercan, 2006; Serinikli ve nan, 2007; Ünal ve ark., 2009).

\footnotetext{
${ }^{1}$ Bu araştırma TÜB TAK tarafından Proje No: 1090609 ile desteklenmiştir

*Sorumlu yazar: Şahin, A., ahmet.sahin@ ksu.edu.tr
} 
Özüdoğru (2004) tarafından yapılan çalışmada yöneticilerin kooperatif işletmelerin başarısı üzerine olabilecek etkileri değerlendirilmiş ve yetenekli yöneticilerin başarıda belirleyici olduğu kanısına varılmıştır. Cook (1995) yaptığı çalışmada yönetici davranışlarının tarımsal kooperatifler üzerine etkisini ortaya konmuştur.

Türkiye Kooperatifçilik Stratejisi ve Eylem Planında; Kooperatif yöneticilerinin işletme yönetimi konusunda bilgi ve deneyim eksikliği, profesyonel yönetici istihdam edilememesi, Yönetim kurulu üyeliği için eğitim ve sertifikasyon koşulununun olmaması, Türkiye'de kooperatifçiliğin kurumsal ve profesyonel yönetim eksikliği olarak ile SWOT analiziyle ortaya konulmuştur (Anonim 2014).

Tarımsal kooperatiflerde yönetici özelliklerini araştıran çalışmalar sınırlıdır. Türkiye'de doğrudan tarımsal kalkınma kooperatifi yöneticilerinin özelliklerini ortaya koyan bir çalışmanın olmaması araştırmanın önemini ortaya koymaktadır.

\section{MATERYAL VE YÖNTEM}

$\mathrm{Bu}$ çalışmanın esas materyalini, tarımsal kalkınma kooperatifi yöneticileri ile karşılıklı görüşerek yapılan anketlerden elde edilen orijinal nitelikli veriler oluşturmuştur. Çalışmanın Türkiye'yi temsil etmesi bakımından anketler 7 coğrafi bölgede yapılmıştır. Bölgeleri temsilen, en fazla Tarımsal Kalkınma Kooperatifine sahip birer il seçilmiştir. Her bölgede seçilen il kooperatif sayısı ve ortak sayısı bakımından öne çıkan iller olmuştur. Görüşülecek kooperatif yöneticisi örnek hacminin belirlenmesinde oransal örnek hacmi formülü kullanılmıştır. (Newbold, 1995; Miran, 2002). Formülde;

$$
\begin{aligned}
& n=\frac{N p(1-p)}{(N-1) \sigma_{\hat{p}_{x}}^{2}+p(1-p)} \\
& \sigma_{p_{x}=\text { Oranın Varyansı }}^{2} \\
& \text { n: Örnek hacmi } \\
& \text { N: Anakitle } \\
& \text { p: oran (maksimum örnek hacmine ulaşmak }
\end{aligned}
$$
amacıyla $\mathrm{p}=0.5$ alınmıştır.)

Tarımsal kalkınma kooperatif sayıs1 6049'dır (Anonim 2009). Buna göre, \%90 güven aralığ1 ve \%9 hata payı için örnek hacmi, 84 kooperatif yöneticisi olarak hesaplanmıştır. Örnek hacminin illere dağılımında oransallık dikkate alınmıştır (Çizelge 1).

Çizelge 1. Anket yapılan illerde anket dağılımı

\begin{tabular}{lcccc}
\multicolumn{1}{c}{ Bölgeler } & Kooperatif Sayısı & $\%$ & Yönetici Anketi Sayısı & Anket Yapılan ller \\
\hline Akdeniz & 804 & 13,3 & 11 & Antalya \\
\hline Doğu Anadolu & 615 & 10,2 & 9 & Erzurum \\
\hline Ege & 826 & 13,7 & 11 & zmir \\
\hline Güney Doğu Anadolu & 271 & 4,5 & 4 & Şanliurfa \\
\hline ç Anadolu & 852 & 14,1 & 12 & Konya \\
\hline Karadeniz & 1450 & 24,0 & 20 & Trabzon \\
\hline Marmara & 1231 & 20,4 & 17 & Balıkesir \\
\hline Toplam & 6049 & 100.0 & 84 & \\
\hline
\end{tabular}

\section{BULGULAR}

\section{Kooperatif Yöneticilerinin Özellikleri}

Yöneticilerin ortalama yaşları 48.0 yıl olarak bulunmuştur. En yaşlı kooperatif yöneticileri ortalama 54.0 yıl ile

\begin{tabular}{|c|c|c|c|c|c|}
\hline ller & Yönetici Sayıs1 & Ortalama & Minimum & Maximum & Std. Sapma \\
\hline Antalya & 11 & 43.5 & 31 & 58 & 9.2 \\
\hline Balıkesir & 17 & 42.7 & 24 & 56 & 9.7 \\
\hline Erzurum & 9 & 46.8 & 33 & 58 & 9.1 \\
\hline zmir & 11 & 54.0 & 31 & 70 & 11.4 \\
\hline Konya & 12 & 48.3 & 27 & 60 & 9.4 \\
\hline Şanlıurfa & 4 & 48.3 & 38 & 58 & 8.7 \\
\hline Trabzon & 20 & 52.2 & 39 & 68 & 8.3 \\
\hline Genel Toplam & 84 & 48.0 & 24 & 70 & 10.0 \\
\hline
\end{tabular}
zmir ilinde, en genç yöneticiler ise, ortalama 42.7 yıl ile Balıkesir ilinde bulunmaktadır. Kooperatif işletmeciliğgi deneyimi olan illerde yöneticilerin daha yaşlı olduğu görülmektedir. Görüşülen en genç yönetici 24 yaşında Balıkesir ilinde, en yaşlı yönetici ise 70 yaşında zmir ilinde bulunmaktadır (Çizelge 2).

Çizelge 2. Kooperatif yöneticilerinin yaşları (yıl)

*p<0.05 Kruskal Wallis Testi için anlamlıdır.

Görüşülen yöneticilerin büyük çoğunluğu (\%96.4) erkek, çok azı ise (\%3.6) kadın yöneticilerdir. Kadın yöneticilere Antalya, Balıkesir, ve zmir ilinde rastlanmıştır. Kooperatif yöneticiliğinin ailenin öğrenim 
düzeyinden kaynaklanıp kaynaklamadığını araştırmak üzere yöneticilerin babalarının ve annelerinin öğrenim düzeyleri saptanmıştır. Yöneticilerin babalarının \%88.1'i ilk okul mezunu, \%3.6's1 lise mezunu, \%2.4'ü orta okul mezunu ve \%1.2'si üniversite mezundur; \%3.6'sı ise hiç öğrenim görmemiştir. Babası üniversite mezunu olanların çoğu $(\% 9.1)$ zmir ilinde bulunmaktadır. Lise, orta öğrenim ve öğrenim görememiş oranı Konya ilinde en fazladır. Kooperatif yöneticilerinin annelerinin \%27.4'u öğrenim görmemiştir, \%71.4'ü ilk okul ve \%1.2'si orta okul mezunlarından oluşmaktadır. Yönetici annelerinin öğrenim düzeyleri babalarınkinden daha düşüktür. Şanlıurfa ilinde bulunan yönetici annelerinin hiçbiri öğrenim görmemiştir. zmir ilinde ise yönetici annelerinin tamamı ilkokul mezunudur. Kooperatif yöneticilerinin \%35.7'si ilkokul mezunu, \%28.6's1 lise mezunu, \%16.7'si üniversite mezunu ve \%15.5'i orta okul mezunudur. Yöneticilerin anne ve babalarına oranla öğrenim düzeyleri daha yüksektir. Antalya, Balıkesir, Erzurum ve Konya illerinde ilkokul mezunu yöneticisi daha fazladır. zmir ve Şanlıurfa illerinde üniversite mezunu yönetici oranı diğer illere oranla yüksektir. Şanlıurfa ilinde görüşülen kooperatiflerden birisinin üniversite mezunları tarafından kurulmuş olması bunda etkili olmuştur. Trabzon ilinde lise mezunlarının oranı en fazladır (Çizelge 3).

Çizelge 3. Kooperatif yöneticilerinin öğrenim durumu (\%)

\begin{tabular}{lccccrr}
\multicolumn{1}{c}{ ller } & lk Okul & Orta Okul & Lise & MYO & Üniversite & Toplam \\
\hline Antalya & 63.6 & 0.0 & 27.3 & 0.0 & 9.1 & 100.0 \\
\hline Balıkesir & 35.3 & 11.8 & 29.4 & 5.9 & 17.6 & 100.0 \\
\hline Erzurum & 55.6 & 33.3 & 11.1 & 0.0 & 0.0 & 100.0 \\
\hline zmir & 18.2 & 18.2 & 27.3 & 0.0 & 36.4 & 100.0 \\
\hline Konya & 41.7 & 25.0 & 25.0 & 8.3 & 0.0 & 100.0 \\
\hline Şanliurfa & 0.0 & 25.0 & 25.0 & 0.0 & 50.0 & 100.0 \\
\hline Trabzon & 25.0 & 10.0 & 40.0 & 5.0 & 20.0 & 100.0 \\
\hline Genel Toplam & 35.7 & 15.5 & 28.6 & 3.6 & 16.7 & 100.0 \\
\hline
\end{tabular}

Yöneticilerin ortalama kooperatif deneyimi 10.3 yıldır. Kooperatif deneyimi olmayan daha yeni başlayan yöneticiler olduğu gibi 39 yıllık deneyimi olanlarda vardır. Kooperatifçilik deneyimi geçmiş yıllara dayalı olan zmir ilinde 17.9 yıl olarak belirlenmiştir. Ortalama deneyim süresinin en düşük olduğu il 4.5 ile Balıkesir ilidir (Çizelge 4).

Çizelge 4. Kooperatif yöneticilerinin kooperatif deneyimi (yıl)

\begin{tabular}{|c|c|c|c|c|}
\hline ller & Ortalama & Minimum & Maximum & Std. Sapma \\
\hline Antalya & 8.2 & 2.0 & 20.0 & 5.5 \\
\hline Balıkesir & 4.5 & 0.0 & 8.0 & 2.4 \\
\hline Erzurum & 5.0 & 0.0 & 9.0 & 3.0 \\
\hline zmir & 17.9 & 6.0 & 30.0 & 9.3 \\
\hline Konya & 9.4 & 1.0 & 33.0 & 11.3 \\
\hline Şanliurfa & 4.8 & 2.0 & 10.0 & 3.6 \\
\hline Trabzon & 16.3 & 2.0 & 39.0 & 10.0 \\
\hline Genel Toplam & 10.3 & 0.0 & 39.0 & 9.2 \\
\hline
\end{tabular}

$* \mathrm{p}<0.05$ Kruskal Wallis Testi için anlamlıdır.

Görüşülen kooperatif yöneticilerinin \%76.2'si tarım dışında bir mesleği olduğunu beyan etmiştir. Tarım dışı mesleği olmayan yöneticiler \%54.5 ile en fazla Antalya ilindedir (Çizelge 5).

Çizelge 5. Kooperatif yöneticilerinin tarım dışı mesleği olma durumu (\%)

\begin{tabular}{lccc}
\multicolumn{1}{c}{ ller } & $\begin{array}{c}\text { Tarım Dişı Mesleği } \\
\text { Olmayan }\end{array}$ & $\begin{array}{c}\text { Tarım Dişı } \\
\text { Mesleği Olan }\end{array}$ & Toplam \\
\hline Antalya & 54.5 & 45.5 & 100.0 \\
\hline Balıkesir & 29.4 & 70.6 & 100.0 \\
\hline Erzurum & 0.0 & 100.0 & 100.0 \\
\hline zmir & 18.2 & 81.8 & 100.0 \\
\hline Konya & 58.3 & 41.7 & 100.0 \\
\hline Şanlıurfa & 0.0 & 100.0 & 100.0 \\
\hline Trabzon & 0.0 & 100.0 & 100.0 \\
\hline Genel Toplam & 23.8 & 76.2 & 100.0
\end{tabular}


Kooperatif yöneticilerinin yarıdan fazlası (\%53.6) kooperatifçilik konusunda herhangi bir eğitim almamıştır. Eğitim alan yöneticilerin oranı \%70.0 ile Trabzon ilinde en yüksektir. Bu ili \%55.6'lık oranla Erzurum ili izlemektedir. Kooperatifçilik konusunda eğitim alamayanların oranı \%75.0'lik en yüksek oranla Şanlıurfa ilindedir (Çizelge 6). Gümrük ve Ticaret Bakanlığı ve Gıda Tarım ve Hayvancılık Bakanlığı tarafından 2008 yılında gerçekleştirilen "Kooperatifçilik Sektörü Anket Çalışmasında ulaşılmıştır; ankete katılan yönetici ve ortakların büyük çoğunluğunun kooperatifçilik konusunda hiçbir eğitim almadıkları yönünde bulgulara rastlanılmıştır (Anonim 2014). Sürdürülebilir bir kooperatifçilik ve yöneticilik için mutlaka başta yöneticiler olmak üzere tüm ortakların, çalışanların eğitilmesi gereklidir. Bu konuda tarım teşkilatının yayım birimlerinin ve kooperatiflerin resmi işlerini takip eden birimlerin hizmet içi eğitim programları düzenlemeleri gerekmektedir. Bu konuya özel danışmanlık büroları da katkı sağlayabilir.

Çizelge 6. Kooperatif yöneticilerinin kooperatifçilik eğitimi alma durumu (\%)

\begin{tabular}{lccc}
\multicolumn{1}{c}{ ller } & Eğitim Alan & Eğitim Almayan & Toplam \\
\hline Antalya & 36.4 & 63.6 & 100.0 \\
\hline Balıkesir & 35.3 & 64.7 & 100.0 \\
\hline Erzurum & 55.6 & 44.4 & 100.0 \\
\hline zmir & 36.4 & 63.6 & 100.0 \\
\hline Konya & 41.7 & 58.3 & 100.0 \\
\hline Şanliurfa & 25.0 & 75.0 & 100.0 \\
\hline Trabzon & 70.0 & 30.0 & 100.0 \\
\hline Genel Toplam & 46.4 & 53.6 & 100.0
\end{tabular}

Kooperatif yöneticilerinin \%32.1'i yurt dişına çıkmış iken, \%67.9 gibi bir çoğunluğu henüz yurt dişına çıkmamıştır. Yurt dışına çıkma oranı \%54.5 ile zmir ilinde en yüksektir. Erzurum ilindeki yöneticilerin hiç biri yurt dışına çıkmamıştır (Çizelge 7).

Çizelge 7. Kooperatif yöneticilerinin yurt dişına çıkma durumu (\%)

\begin{tabular}{lccc}
\multicolumn{1}{c}{ ller } & Yurt Dişına Çıkan & Yurt Dişına Çıkmayan & Toplam \\
\hline Antalya & 27.3 & 72.7 & 100.0 \\
\hline Balıkesir & 41.2 & 58.8 & 100.0 \\
\hline Erzurum & 0.0 & 100.0 & 100.0 \\
\hline zmir & 54.5 & 45.5 & 100.0 \\
\hline Konya & 25.0 & 75.0 & 100.0 \\
\hline Şanliurfa & 25.0 & 75.0 & 100.0 \\
\hline Trabzon & 35.0 & 65.0 & 100.0 \\
\hline Genel Toplam & 32.1 & 67.9 & 100.0
\end{tabular}

Yurt dişındaki kooperatifleri ziyaret eden yönetici oranı yalnızca \%9.5'dir. Yöneticilerin \%90.5'i yurt dışında kooperatif ziyareti yapmamıştır (Çizelge 8). Vizyon sahibi olmak, eğitimli olmanın yanı sıra gezipdeneyimlemeyi de gerektirir. Özellikle uluslararası rekabete konu olmuş kooperatif vb. işletmelerde vizyon sahibi olmak kooperatifin başarısı ve zamanın değişen koşullarına uyum sağlanabilmesi açısından oldukça önemlidir.

Çizelge 8. Kooperatif yöneticilerinin yurt dişına kooperatif ziyareti durumu (\%)

\begin{tabular}{lccc}
\multicolumn{1}{c}{ ller } & $\begin{array}{c}\text { Yurt Dişında Kooperatif } \\
\text { Ziyaret Eden }\end{array}$ & $\begin{array}{c}\text { Yurt Dişında Kooperatif } \\
\text { Ziyaret Etmeyen }\end{array}$ & Toplam \\
\hline Antalya & 18.2 & 81.8 & 100.0 \\
\hline Balıkesir & 17.6 & 82.4 & 100.0 \\
\hline Erzurum & 0.0 & 100.0 & 100.0 \\
\hline zmir & 9.1 & 90.9 & 100.0 \\
\hline Konya & 0.0 & 100.0 & 100.0 \\
\hline Şanlıurfa & 25.0 & 75.0 & 100.0 \\
\hline Trabzon & 5.0 & 95.0 & 100.0 \\
\hline Genel Toplam & 9.5 & 90.5 & 100.0 \\
\hline
\end{tabular}


Kooperatif yöneticilerin $\% 73.8$ gibi büyük bir çoğunluğu yurt içinde kooperatif ziyaretinde bulunmuştur. Yurt içinde kooperatif ziyaret etmeyen oranı Antalya ilinde en yüksektir (Çizelge 9). Yurtiçinde bölgeler arası ekonomik, toplumsal ve kültürel gelişmişlik farkları, insan kaynakları profilini değiştirmektedir. Söz konusu edinilen deneyimler kooperatif işletmelerin başarılarını direkt olarak etkilemektedir. $\mathrm{Bu}$ açıdan başarılı kooperatif işletmelerin başarı hikâyelerini yerinde görmek kooperatif yönetici ve ortakları açısından önemlidir.

Çizelge 9. Kooperatif yöneticilerinin yurt içinde kooperatif ziyareti durumu (\%)

\begin{tabular}{lccc}
\multicolumn{1}{c}{ ller } & $\begin{array}{c}\text { Yurt çinde Kooperatif } \\
\text { Ziyaret Eden }\end{array}$ & $\begin{array}{c}\text { Yurt çinde Kooperatif } \\
\text { Ziyaret Etmeyen }\end{array}$ & Toplam \\
\hline Antalya & 45.5 & 54.5 & 100.0 \\
\hline Balıkesir & 76.5 & 23.5 & 100.0 \\
\hline Erzurum & 77.8 & 22.2 & 100.0 \\
\hline zmir & 81.8 & 18.2 & 100.0 \\
\hline Konya & 58.3 & 41.7 & 100.0 \\
\hline Şanliurfa & 100.0 & 0.0 & 100.0 \\
\hline Trabzon & 85.0 & 15.0 & 100.0 \\
\hline Genel Toplam & 73.8 & 26.2 & 100.0 \\
\hline
\end{tabular}

Her yöneticinin kooperatif deneyimi kişisel olmayabilir, ancak aileden gelen bir deneyimleri söz konusu olup olmadığı sorgulanmıştır. Yöneticilerin \%81.0'nin ailesinde daha önce yönetici olmamıştır. Ailesinde daha önce yönetici deneyimi olanların oranı $\% 45$ ile Trabzon ilinde en yüksektir (Çizelge 10).

Çizelge 10. Kooperatif yöneticilerinin ailesinden daha önce yönetici olma durumu (\%)

\begin{tabular}{|c|c|c|c|}
\hline ller & Aileden Yönetici Olmuş & Aileden Yönetici Olmamış & Toplam \\
\hline Antalya & 27.3 & 72.7 & 100.0 \\
\hline Balıkesir & 5.9 & 94.1 & 100.0 \\
\hline Erzurum & 0.0 & 100.0 & 100.0 \\
\hline zmir & 18.2 & 81.8 & 100.0 \\
\hline Konya & 8.3 & 91.7 & 100.0 \\
\hline Şanlıurfa & 0.0 & 100.0 & 100.0 \\
\hline Trabzon & 45.0 & 55.0 & 100.0 \\
\hline Genel Toplam & 19.0 & 81.0 & 100.0 \\
\hline
\end{tabular}

*p<0.05 Kruskal Wallis Testi için anlamlıdır.

Kooperatif yöneticilerin son öğrenim gördükleri yer $\% 45.2$ oranı ile il merkezi, \%35.7 ile köy ve \%19.0 ile ilçe merkezidir. Erzurum'da en son köyde öğrenim görenlerin oranı \%55.6 ile en yüksektir (Çizelge 11).

Çizelge 11. Kooperatif yöneticilerinin en son öğrenim gördükleri yer (\%)

\begin{tabular}{lcccc}
\multicolumn{1}{c}{ ller } & 1 & lçe & Köy & Toplam \\
\hline Antalya & 18.2 & 27.3 & 54.5 & 100.0 \\
\hline Balıkesir & 58.8 & 0.0 & 41.2 & 100.0 \\
\hline Erzurum & 22.2 & 22.2 & 55.6 & 100.0 \\
\hline zmir & 54.5 & 18.2 & 27.3 & 100.0 \\
\hline Konya & 33.3 & 25.0 & 41.7 & 100.0 \\
\hline Şanliurfa & 100.0 & 0.0 & 0.0 & 100.0 \\
\hline Trabzon & 50.0 & 30.0 & 20.0 & 100.0 \\
\hline Genel Toplam & 45.2 & 19.0 & 35.7 & 100.0 \\
\hline
\end{tabular}

Kooperatif yöneticileri ortalama 12.7 yıldır kooperatif ortağıdırlar. Ortaklık deneyimi çok yeni olanlar olduğu gibi, 40 yıldır kooperatife ortak olanlar da vardır. Ortaklık süresi en yüksek yöneticiler 24.8 yıl ile zmir ilinde bulunmaktadır. Ortaklık süresi en az olan yöneticiler Şanlıurfa ilinde bulunmaktadır (Çizelge 12). 
Çizelge 12. Kooperatif yöneticilerinin ortaklık süresi (y1l)

\begin{tabular}{|c|c|c|c|c|}
\hline ller & Ortalama & Minimum & Maximum & Std. Sapma \\
\hline Antalya & 10.6 & 3.0 & 20.0 & 6.5 \\
\hline Balıkesir & 5.1 & 0.0 & 8.0 & 1.9 \\
\hline Erzurum & 4.9 & 0.0 & 9.0 & 2.9 \\
\hline zmir & 24.8 & 6.0 & 40.0 & 12.6 \\
\hline Konya & 14.3 & 1.0 & 38.0 & 12.9 \\
\hline Şanlıurfa & 4.5 & 3.0 & 8.0 & 2.4 \\
\hline Trabzon & 17.7 & 2.0 & 39.0 & 9.9 \\
\hline Genel Toplam & 12.7 & 0.0 & 40.0 & 10.9 \\
\hline
\end{tabular}

*p $<0.05$ Kruskal Wallis Testi için anlamlıdır.

\section{Yöneticilerin Görevleri}

Kooperatif yöneticilerinin kooperatifteki ortalama yöneticilik deneyim süresi 6.2 yıldır. zmir ili 9.5 yıl ile yöneticilik deneyimi en fazla olan ildir. Bu sayı, Konya ilinde $33 \mathrm{y}$ yl, $\quad$ zmir ilinde ise 25 yıldır (Çizelge 13). Yöneticilerin uzun süre değişmemesi kooperatifçilik ilke ve felsefesi açısından doğru değildir. Bu durum değişime, gelişime ve sürdürülebilir kooperatif̧̧iliğe katkı sağlamamaktadır. Kooperatif yöneticilerinin \%60.7 gibi bir çoğunluğu görevi ile ilgili ücret almazken, \%39.3'ü ücret almaktadır. Ücret alma oranı $\% 75.0$ ile Trabzon ilinde en yüksektir. Bu ili \%72.7 ile Antalya ili izlemektedir. Erzurum ve Şanlıurfa illerinde yöneticiler görevleri ile ilgili ücret almamaktadır (Çizelge 14). Görüşülen kooperatif yöneticilerinin \%26.2'si Yönetim Kurulu Başkanı, \%23.8'i Yönetim Kurulu Üyesi, \%20.2'si Denetim Kurulu Üyesi ve \%19.0'u Yönetim Kurulu Başkan Yardımcısıdır (Çizelge 15).

Çizelge 13. Kooperatif yöneticilerinin yönetim deneyimi (yıl)

\begin{tabular}{|c|c|c|c|c|}
\hline 1ler & Ortalama & Minimum & Maximum & Std. Sapma \\
\hline Antalya & 7.5 & 2.0 & 19.0 & 5.5 \\
\hline Balıkesir & 4.5 & 1.0 & 7.0 & 2.1 \\
\hline Erzurum & 3.9 & 2.0 & 9.0 & 2.5 \\
\hline zmir & 9.5 & 1.0 & 25.0 & 10.1 \\
\hline Konya & 8.9 & 1.0 & 33.0 & 11.5 \\
\hline Şanlıurfa & 4.0 & 1.0 & 8.0 & 2.9 \\
\hline Trabzon & 4.8 & 1.0 & 22.0 & 6.0 \\
\hline Genel Toplam & 6.2 & 1.0 & 33.0 & 6.9 \\
\hline
\end{tabular}

Çizelge 14. Kooperatif yöneticilerinin görevi ile ilgili ücret alma durumu (\%)

\begin{tabular}{lccc}
\multicolumn{1}{c}{ ller } & Ücret Alan & Ücret Almayan & Toplam \\
\hline Antalya & 72.7 & 27.3 & 100.0 \\
\hline Balıkesir & 23.5 & 76.5 & 100.0 \\
\hline Erzurum & 0.0 & 100.0 & 100.0 \\
\hline zmir & 18.2 & 81.8 & 100.0 \\
\hline Konya & 33.3 & 66.7 & 100.0 \\
\hline Şanliurfa & 0.0 & 100.0 & 100.0 \\
\hline Trabzon & 75.0 & 25.0 & 100.0 \\
\hline Genel Toplam & 39.3 & 60.7 & 100.0 \\
\hline
\end{tabular}

*p<0.05 Kruskal Wallis Testi için anlamlıdır.

Çizelge 15. Kooperatif yöneticilerinin yönetimdeki görevleri (\%)

\begin{tabular}{lcrrrrrr}
\multicolumn{1}{c}{ ller } & $\begin{array}{c}\text { Yön. Kur. } \\
\text { Başkanı }\end{array}$ & $\begin{array}{c}\text { Yön. Kur. } \\
\text { Bşk. Yard. }\end{array}$ & $\begin{array}{c}\text { Yön. Kur. } \\
\text { Üyesi }\end{array}$ & $\begin{array}{c}\text { Denetim. Kur. } \\
\text { Üyesi }\end{array}$ & $\begin{array}{c}\text { Kooperatif } \\
\text { Müdürü }\end{array}$ & Diğer & Toplam \\
\hline Antalya & 27.3 & 18.2 & 27.3 & 18.2 & 0.0 & 9.1 & 100.0 \\
\hline Balıkesir & 17.6 & 11.8 & 23.5 & 29.4 & 0.0 & 17.6 & 100.0 \\
\hline Erzurum & 22.2 & 33.3 & 11.1 & 22.2 & 0.0 & 11.1 & 100.0 \\
\hline zmir & 18.2 & 18.2 & 45.5 & 9.1 & 0.0 & 9.1 & 100.0 \\
\hline Konya & 33.3 & 25.0 & 25.0 & 16.7 & 0.0 & 0.0 & 100.0 \\
\hline Şanliurfa & 100.0 & 0.0 & 0.0 & 0.0 & 0.0 & 0.0 & 100.0 \\
\hline Trabzon & 20.0 & 20.0 & 20.0 & 25.0 & 10.0 & 5.0 & 100.0 \\
\hline Genel Toplam & 26.2 & 19.0 & 23.8 & 20.2 & 2.4 & 8.3 & 100.0 \\
\hline
\end{tabular}


Yöneticilerinin \%77.4 gibi bir çoğunluğu kooperatif üst birliklerinde görev almamaktadır. Görev alanlar kooperatif yöneticilerinin \%22.6'sını oluşturmaktadır.
Üst birliklerde görev alma zmir ilinde $\% 45.5$ ile en yüksek ve \%11.1 ile Erzurum ilinde en düşük orandadır (Çizelge 16).

Çizelge 16. Kooperatif yöneticilerinin üst birliklerde görev alma durumu (\%)

\begin{tabular}{lccc}
\multicolumn{1}{c}{ ller } & Görev Alan & Görev Almayan & Toplam \\
\hline Antalya & 18.2 & 81.8 & 100.0 \\
\hline Balıkesir & 11.8 & 88.2 & 100.0 \\
\hline Erzurum & 11.1 & 88.9 & 100.0 \\
\hline zmir & 45.5 & 54.5 & 100.0 \\
\hline Konya & 16.7 & 83.3 & 100.0 \\
\hline Şanliurfa & 25.0 & 75.0 & 100.0 \\
\hline Trabzon & 30.0 & 70.0 & 100.0 \\
\hline Genel Toplam & 22.6 & 77.4 & 100.0 \\
\hline
\end{tabular}

Yöneticilerin Kooperatif lkelerini Bilme Durumu

Kooperatif yöneticilerine uluslararası kooperatifçilik ilkelerinin sayısı sorulmuştur. Yöneticilerin \%40.5'i ilke sayısını bilmediğini ifade etmiştir. lke sayısının üç olduğunu söyleyen yönetici oranı \%19.0'dur. Kooperatifçilik ilkeleri sayısının yedi olduğunu doğru bilen yönetici oranı \%14.3'dür. Yedi ilkeyi en fazla bilme oranı Antalya'da \%36.4 ile en yüksektir. Antalya ili \%36'4'lük oranla yedi ilkenin tam olarak bilindiği ilk sıradaki ildir. lkeleri bilmememe oranı \%72.7 ile zmir ilinde en yüksektir (Çizelge 17).

Çizelge 17. Kooperatif yöneticilerinin kooperatif ilkeleri sayısı tahmini

\begin{tabular}{lcccccccc}
\hline & Antalya & Balikesir & Erzurum & zmir & Konya & Şanliurfa & Trabzon & Genel Toplam \\
\hline Bilinmeyen ilke sayıs1 & 54.5 & 58.8 & 22.2 & 72.7 & 66.7 & 0.0 & 0.0 & 40.5 \\
\hline 1 ilke & 0.0 & 0.0 & 0.0 & 0.0 & 0.0 & 50.0 & 0.0 & 2.4 \\
\hline 2 ilke & 0.0 & 0.0 & 22.2 & 9.1 & 8.3 & 25.0 & 10.0 & 8.3 \\
\hline 3 ilke & 9.1 & 0.0 & 33.3 & 9.1 & 0.0 & 25.0 & 50.0 & 19.0 \\
\hline 4 ilke & 0.0 & 0.0 & 22.2 & 0.0 & 8.3 & 0.0 & 25.0 & 9.5 \\
\hline 5 ilke & 0.0 & 0.0 & 0.0 & 0.0 & 8.3 & 0.0 & 10.0 & 3.6 \\
\hline 6 ilke & 0.0 & 0.0 & 0.0 & 0.0 & 0.0 & 0.0 & 5.0 & 1.2 \\
\hline 7 ilke & 36.4 & 35.3 & 0.0 & 9.1 & 8.3 & 0.0 & 0.0 & 14.3 \\
\hline 12 ilke & 0.0 & 5.9 & 0.0 & 0.0 & 0.0 & 0.0 & 0.0 & 1.2 \\
\hline Toplam & 100.0 & 100.0 & 100.0 & 100.0 & 100.0 & 100.0 & 100.0 & 100.0 \\
\hline
\end{tabular}

Kooperatif yöneticilerinin kooperatif ilkelerini bilip bilmedikleri ilkeler söylenerek tek tek sorgulanmıştır. Serbest giriş: gönüllü ve açık ortaklık ilkesini yöneticilerin \%45.2'si bilmektedir. Hiç bilemeyenlerin oranı \%29.8 ve sadece adını bilenlerin oranı \%25.0'dır. $\mathrm{Bu}$ ilkenin ne olduğunu hiç bilemeyenlerin oranı zmir ilinde \%45.5 ile en yüksektir (Çizelge 18).

Çizelge 18. Yöneticilerin "serbest giriş: gönüllü ve açık ortaklık” ilkesini bilme durumu

\begin{tabular}{lcccc}
\multicolumn{1}{c}{ ller } & Hiç Bilmiyor & Sadece Adını Biliyor & Ne Olduğunu Biliyor & Toplam \\
\hline Antalya & 36.4 & 9.1 & 54.5 & 100.0 \\
\hline Balıkesir & 29.4 & 17.6 & 52.9 & 100.0 \\
\hline Erzurum & 22.2 & 55.6 & 22.2 & 100.0 \\
\hline zmir & 45.5 & 18.2 & 36.4 & 100.0 \\
\hline Konya & 50.0 & 8.3 & 41.7 & 100.0 \\
\hline Şanliurfa & 25.0 & 0.0 & 75.0 & 100.0 \\
\hline Trabzon & 10.0 & 45.0 & 45.0 & 100.0 \\
\hline Genel Toplam & 29.8 & 25.0 & 45.2 & 100.0 \\
\hline
\end{tabular}

$* \mathrm{p}<0.05$ Kruskal Wallis Testi için anlamlıdır.

Kooperatif yöneticilerinin \%66.7'si demokratik yönetim: demokratik ortak kontrolü ilkesinin ne dolduğunu bilmektedir. Yöneticilerin \%17.9'u bu ilkeyi hiç duymadığını ve \%15.5'i bu ilkenin adını bildiğini 
fakat içeriğini bilmediğini ifade etmiştir. Demokratik yönetim ilkesinin hiç bilinmeme oranı \%44.4 ile

Erzurum ilinde en yüksektir (Çizelge 19).

Çizelge 19. Yöneticilerin “demokratik yönetim” ilkesini bilme durumu

\begin{tabular}{lcccc}
\multicolumn{1}{c}{ ller } & Hiç Bilmiyor & Sadece Adını Biliyor & Ne Olduğunu Biliyor & Toplam \\
\hline Antalya & 18.2 & 9.1 & 72.7 & 100.0 \\
\hline Balıkesir & 17.6 & 11.8 & 70.6 & 100.0 \\
\hline Erzurum & 44.4 & 11.1 & 44.4 & 100.0 \\
\hline zmir & 9.1 & 27.3 & 63.6 & 100.0 \\
\hline Konya & 41.7 & 16.7 & 41.7 & 100.0 \\
\hline Şanliurfa & 0.0 & 0.0 & 100.0 & 100.0 \\
\hline Trabzon & 0.0 & 20.0 & 80.0 & 100.0 \\
\hline Genel Toplam & 17.9 & 15.5 & 66.7 & 100.0 \\
\hline
\end{tabular}

Kooperatif yöneticilerinin \%41.7'si ortağın ilkesini hiç bilmeyenlerin oranı Konya ilinde \%66.7 ile ekonomik katılımını içeren "risturn ilkesinin" ne en yüksek, ne olduğunu bilenlerin oranı \%72.7 ile zmir olduğunu bilmektedir. lkeyi hiç bilmeyenlerin oranı ilinde en yüksektir (Çizelge 20).

$\% 34.5$ ve sadece adını bilenler \%23.8'dir. Risturn

Çizelge 20. Yöneticilerin "risturn" ilkesini bilme durumu

\begin{tabular}{lcccc}
\multicolumn{1}{c}{ ller } & Hiç Bilmiyor & Sadece Adını Biliyor & Ne Olduğunu Biliyor & Toplam \\
\hline Antalya & 63.6 & 0.0 & 36.4 & 100.0 \\
\hline Balıkesir & 47.1 & 23.5 & 29.4 & 100.0 \\
\hline Erzurum & 33.3 & 44.4 & 22.2 & 100.0 \\
\hline zmir & 18.2 & 9.1 & 72.7 & 100.0 \\
\hline Konya & 66.7 & 25.0 & 8.3 & 100.0 \\
\hline Sanliurfa & 25.0 & 25.0 & 50.0 & 100.0 \\
\hline Trabzon & 0.0 & 35.0 & 65.0 & 100.0 \\
\hline Genel Toplam & 34.5 & 23.8 & 41.7 & 100.0 \\
\hline
\end{tabular}

*p<0.05 Kruskal Wallis Testi için anlamlıdır.

Kooperatif yöneticilerinin yarısı "özerklik ve bağımsızlık ilkesinin" ne olduğunu bilmekte, \%27.4'u hiç bilmemekte, \%22.6'sı ise sadece adını bilmektedir.
Hiç bilemeyenlerin oranı \%58.3 ile Konya ilinde en yüksek, ne olduğunu bilenlerin oranı \%80 ile Trabzon ilinde en yüksektir (Çizelge 21).

Çizelge 21. Yöneticilerin "özerklik ve bă̆ımsızlık" ilkesini bilme durumu

\begin{tabular}{lcccc}
\multicolumn{1}{c}{ ller } & Hiç Bilmiyor & Sadece Adını Biliyor & Ne Olduğunu Biliyor & Toplam \\
\hline Antalya & 18.2 & 27.3 & 54.5 & 100.0 \\
\hline Balıkesir & 29.4 & 23.5 & 47.1 & 100.0 \\
\hline Erzurum & 44.4 & 11.1 & 44.4 & 100.0 \\
\hline zmir & 45.5 & 27.3 & 27.3 & 100.0 \\
\hline Konya & 58.3 & 16.7 & 25.0 & 100.0 \\
\hline Şanliurfa & 0.0 & 50.0 & 50.0 & 100.0 \\
\hline Trabzon & 0.0 & 20.0 & 80.0 & 100.0 \\
\hline Genel Toplam & 27.4 & 22.6 & 50.0 & 100.0 \\
\hline
\end{tabular}

Kooperatif yöneticilerinin \%41.7'si eğitim, öğretim ve bilgi ilkesinin ne anlama geldiğini bildiğini \%31.0'i sadece adını bildiğini, \%27.4'ü ise ilkeyi hiç bilmediğini ifade etmiştir. lkenin hiç bilinmeme oranı \%77.8 ile Erzurum ilinde en yüksek, ne olduğunu bilme oranı \%88.2 ile Balıkesir ilinde en yüksektir (Çizelge 22).

Yöneticilerinin \%56.0'sı "kooperatifler arası işbirliği ilkesinin" ne anlama geldiğini bildiğini, \%23.8'i sadece adını bildiğini, \%20.2'si ise ilkenin ne anlama geldiğini hiç bilmediğini ifade etmiştir. Hiç bilinmeme oranı \%45.5 ile Erzurum ilinde en yüksek, ne olduğunu bilme oranı \%75.0 ile Şanlıurfa ilinde en yüksektir (Çizelge 23).

Kooperatif yöneticilerinin \%45.2'si toplumsal sorumluluk ilkesinin ne anlama geldiğini bildiğini \%28.6'sı sadece adını biliyor, \%26.2'si ise ilkeyi hiç bilmiyor. Hiç bilmeme oranı \%55.6 ile Erzurum ilinde en yüksektir (Çizelge 24). 
Çizelge 22. Yöneticilerin "eğitim, öğretim ve bilgi" ilkesini bilme durumu

\begin{tabular}{lcrrc}
\multicolumn{1}{c}{ ller } & Hiç Bilmiyor & Sadece Adını Biliyor & Ne Olduğunu Biliyor & Toplam \\
\hline Antalya & 0.0 & 45.5 & 54.5 & 100.0 \\
\hline Balıkesir & 11.8 & 0.0 & 88.2 & 100.0 \\
\hline Erzurum & 77.8 & 11.1 & 11.1 & 100.0 \\
\hline zmir & 36.4 & 36.4 & 27.3 & 100.0 \\
\hline Konya & 25.0 & 41.7 & 33.3 & 100.0 \\
\hline Şanlıurfa & 0.0 & 50.0 & 50.0 & 100.0 \\
\hline Trabzon & 35.0 & 45.0 & 20.0 & 100.0 \\
\hline Genel Toplam & 27.4 & 31.0 & 41.7 & \\
\hline
\end{tabular}

Çizelge 23. Yöneticilerin "kooperatifler arası iş birliğii” ilkesini bilme durumu

\begin{tabular}{lcccc}
\multicolumn{1}{c}{ ller } & Hiç Bilmiyor & Sadece Adını Biliyor & Ne Olduğunu Biliyor & Toplam \\
\hline Antalya & 9.1 & 27.3 & 63.6 & 100.0 \\
\hline Balıkesir & 17.6 & 11.8 & 70.6 & 100.0 \\
\hline Erzurum & 44.4 & 0.0 & 55.6 & 100.0 \\
\hline zmir & 45.5 & 9.1 & 45.5 & 100.0 \\
\hline Konya & 25.0 & 33.3 & 41.7 & 100.0 \\
\hline Şanlıurfa & 25.0 & 0.0 & 75.0 & 100.0 \\
\hline Trabzon & 0.0 & 50.0 & 50.0 & 100.0 \\
\hline Genel Toplam & 20.2 & 23.8 & 56.0 & \\
\hline
\end{tabular}

$* \mathrm{p}<0.05$ Kruskal Wallis Testi için anlamlıdır.

Çizelge 24. Yöneticilerin “toplumsal sorumluluk” ilkesini bilme durumu

\begin{tabular}{lcccc}
\multicolumn{1}{c}{ ller } & Hiç Bilmiyor & Sadece Adını Biliyor & Ne Olduğunu Biliyor & Toplam \\
\hline Antalya & 27.3 & 0.0 & 72.7 & 100.0 \\
\hline Balıkesir & 17.6 & 11.8 & 70.6 & 100.0 \\
\hline Erzurum & 55.6 & 44.4 & 0.0 & 100.0 \\
\hline zmir & 36.4 & 18.2 & 45.5 & 100.0 \\
\hline Konya & 16.7 & 33.3 & 50.0 & 100.0 \\
\hline Şanlıurfa & 0.0 & 0.0 & 100.0 & 100.0 \\
\hline Trabzon & 25.0 & 60.0 & 15.0 & 100.0 \\
\hline Genel Toplam & 26.2 & 28.6 & 45.2 & 100.0 \\
\hline
\end{tabular}

\section{Kooperatif Başarısı}

Kooperatif yöneticileri genel olarak kooperatiflerini başarılı görmek eğilimindedir. Serbest giriş ilkesi ve demokratik yönetim ilkesi" açısından yöneticiler kooperatiflerini beşli likerte göre 4.3 değeri ile oldukça başarılı bulmuşlardır. En başarısız ilke uygulaması 2.0 ölçekle risturn ilkesidir. Özerklik ve bağımsızlık ilkesi başarılı düzeye çok yakındır. Eğitim, öğretim ve bilginin yaygınlaştırılması, kooperatifler arası işbirliğ ve toplumsal sorumluluk ilkesi açısından kooperatifler orta düzeyde başarılı bulunmuştur. Serbest giriş ilkesi ortalama 4.6 ile Balıkesir ilinde en yüksek, 3.1 ile zmir ilinde en düşük bulunmuştur. Demokratik yönetim ilkesi 4.7 ile Antalya ilinde en yüksek, 3.7 ile Erzurum ilinde en düşüktür. Risturn ilkesi 2.8 ile Trabzon ilinde en yüksek, Konya ilinde 1.2 ile en düşüktür. Kooperatiflerin tamamına yakını risturn ödemesi yapmadığını, yalnızca Antalya ve Trabzon'da bir iki kooperatif risturn ödediğini belirtmiştir. Özerklik ve bağımsızlık ilkesi 4.5 ile Antalya ilinde en yüksek, 3.6 ile zmir ilinde en düşüktür. Kooperatifler ilişkili oldukları kurumlar ve içerisinde bulundukları toplumun politik görüşleri nedeniyle tam bağımsız ve özerk olamadıkları düşüncesindedirler. Kooperatifler arası işbirliği başarısı 1.8 ile Şanlıurfa ilinde en düşük, 4.0 ile Trabzon ilinde en yüksektir. Toplumsal sorumluluk ilkesi 3.2 ile Antalya ilinde en düşüktür (Çizelge 25).

Kooperatif yöneticileri kendi kooperatiflerini 3.8 ile orta düzeyin biraz üzerinde başarılı bulmaktadır. En yüksek başarı düzeyi 4.8 ile Antalya ilinde ve takiben 2.7 ile Balıkesir ilinde saptanmıştır. zmir ilinde 4.4 ve Trabzon ilinde 4.1 ölçekle yöneticiler kooperatiflerini büyük ölçüde başarılı bulmaktadır. Türkiye geneli için yapılan değerlendirme ortalama 2.6 ile orta düzeyin altına düşmüştür. Kendi kooperatifine göre Türkiye genelini başarılı bulan kooperatif yöneticileri Erzurum ilinde bulunmaktadır. Bu yöneticiler Türkiye'de kooperatifçiliği 4.0 ile büyük ölçüde başarılı bulmaktadır (Çizelge 26). 
Çizelge 25. Yöneticilerin kooperatif ilkelerine göre kooperatifi değerlendirmesi

\begin{tabular}{|c|c|c|c|c|c|c|c|c|}
\hline & Antalya & Balıkesir & Erzurum & zmir & Konya & Şanlıurfa & Trabzon & Genel Toplam \\
\hline $\begin{array}{l}\text { Serbest Giriş: Gönüllü ve } \\
\text { açık ortaklık }\end{array}$ & 4.4 & 4.6 & 4.1 & 3.1 & 4.5 & 4.3 & 4.5 & 4.3 \\
\hline $\begin{array}{l}\text { Demokratik Yönetim: } \\
\text { Demokratik Ortak } \\
\text { Kontrolü }\end{array}$ & 4.7 & 4.4 & 3.7 & 4.3 & 4.4 & 4.8 & 3.9 & 4.3 \\
\hline $\begin{array}{l}\text { Ortağın Ekonomik } \\
\text { Katılımı: Risturn }\end{array}$ & 2.6 & 1.3 & 2.3 & 1.8 & 1.2 & 2.3 & 2.8 & 2.0 \\
\hline Özerklik ve Bağımsızlık & 4.5 & 4.1 & 3.9 & 3.6 & 3.9 & 3.8 & 3.8 & 3.9 \\
\hline Eğitim, Öğretim ve Bilgi & 3.6 & 3.9 & 2.6 & 3.9 & 2.6 & 3.8 & 3.0 & 3.3 \\
\hline $\begin{array}{l}\text { Kooperatifler arası iş } \\
\text { birliği }\end{array}$ & 2.9 & 2.9 & 2.1 & 3.5 & 2.9 & 1.8 & 4.0 & 3.1 \\
\hline Toplumsal Sorumluluk & 3.2 & 3.8 & 3.0 & 4.0 & 3.3 & 4.0 & 3.8 & 3.6 \\
\hline
\end{tabular}

Likert: 1:Başarısız, 2: Biraz Başarılı, 3: Orta Düzeyde Başarılı 4: Oldukça Başarılı 5: Çok Başarılı

Çizelge 26. Yöneticilerin kooperatif başarısına ilişkin görüşleri

\begin{tabular}{lcc}
\multicolumn{1}{c}{ ller } & Kooperatifinizin Başarısı & Türkiye'de Kooperatifçiliğin Başarısı \\
\hline Antalya & 4.8 & 2.8 \\
\hline Balıkesir & 2.7 & 1.9 \\
\hline Erzurum & 3.8 & 4.0 \\
\hline zmir & 4.4 & 2.0 \\
\hline Konya & 3.3 & 3.2 \\
\hline Şanliurfa & 3.5 & 1.3 \\
\hline Trabzon & 4.1 & 2.7 \\
\hline Genel Toplam & 3.8 & 2.6 \\
\hline
\end{tabular}

Likert: 1:Başarısız, 2: Biraz Başarılı, 3: Orta Düzeyde Başarılı 4: Büyük Ölçüde Başarılı 5: Kesinlikle Başarılı $* p<0.05$ Kruskal Wallis Testi için anlamlıdır.

Kooperatif yöneticilerine kooperatif başarısının nedenleri açık uçlu olarak sorulmuştur. Verilen cevaplar aşağıdaki gibi özetlenmiştir. Yöneticilerin \%38.9 ile çoğunluğu ortaklar ve yöneticiler arasında birlik ve beraberliğin başarıyı getirdiği kanısındadırlar. kinci sırada, yöneticiler \%21.1 planlı çalışmayı başarıda önemli gördüklerini, pazarlamanın iyi yapılmasını ise \%12.3 ile üçüncü sırada önemli bulmuşlardır. Açık uçlu cevapları kooperatifçilik ilkeleri ile bağdaştırmak mümkündür. Verilen cevapların bir bileşkesi olarak başarı ortaya çıkmaktadır (Çizelge 27).

Çizelge 27. Kooperatif başarısının nedenleri

\begin{tabular}{lrr}
\multicolumn{1}{c}{ Başarı Nedeni } & Tercih & $\%$ \\
\hline Ortaklar ve kooperatif yöneticileri arasında birlik ,beraberlik olması & 35 & 38.9 \\
\hline Planlı ve bilinçli çalışılması & 19 & 21.1 \\
\hline Pazarlamanın iyi yapılması & 11 & 12.2 \\
\hline Ürün işleniyor olması & 5 & 5.6 \\
\hline Yönetim kadrosunun güçlü ve iyi olması & 5 & 5.6 \\
\hline Kooperatifin borcunun olmaması & 3 & 3.3 \\
\hline Şirket ve tüccarların çiftçileri dolandırması & 3 & 3.3 \\
\hline Organizasyon iyi olması & 3 & 3.3 \\
\hline Dürüst çalışılması & 3 & 3.3 \\
\hline Yapilan faaliyetlerin geri dönüşü & 2 & 2.2 \\
\hline Ortakları ödemelerinde düzenli olması & 1 & 1.1 \\
\hline Toplam & 90 & 100.0 \\
\hline
\end{tabular}

Kooperatif yöneticilerine Türkiye'de başarılı bir kooperatifçilik önerilerinin neler olduğu açık uçlu olarak sorulmuştur. Kooperatif yöneticilerinin \%25.0 Türkiye'de başarılı kooperatifçilik için ortakların bilinçlendirilmesi önerisinde bulunmaktadır.
Yöneticilerin \%19.4'ü devlet desteği, \%16.1'i birlik ve beraberlik, \%8.1'i ortakların kooperatifi benimsemesi ve sahip çıkmasını ve $\% 6.5$ 'i ortakların yeni üreticileri bilinçlendirmesi önerisinde bulunmaktadır (Çizelge 28). 
Çizelge 28. Türkiye'de başarılı kooperatifçilik için öneriler

\begin{tabular}{lcc}
\multicolumn{1}{c}{ Öneriler } & Tercih & $\%$ \\
\hline Ortakların bilinçlendirilmesi gerekir & 31 & 25.0 \\
\hline Devlet desteği olmalı & 24 & 19.4 \\
\hline Birlik ve beraberlik & 20 & 16.1 \\
\hline Ortakların kooperatifi benimsemesi ve sahip çıkması gerekmektedir & 10 & 8.1 \\
\hline Ortaklar yani üreticileri bilinçlendirmeli & 8 & 6.5 \\
\hline Özel sektöre göre rekabet şansının yükseltilmesi & 5 & 4.0 \\
\hline Denetim sağlıklı yapıllmalı & 5 & 4.0 \\
\hline Kooperatif kapasiteleri büyük tutulmalı & 3 & 2.4 \\
\hline Kooperatiflerin kuruluş amaçları doğrultusunda hareket etmeli & 3 & 2.4 \\
\hline Bürokrasi azaltılmalı ve üst birlikler sorunu çözülmeli & 4 & 3.2 \\
\hline Kooperatiflerin birleşmesi sağlanmalı & 3 & 2.4 \\
\hline Yönetim kadrosunun güçlü bir organizasyon yapısını sahip olması & 2 & 1.6 \\
\hline Genç çiftçiler kooperatif ortaklığına özendirilmeli & 2 & 1.6 \\
\hline Risturn devamlı verilmeli & 2 & 1.6 \\
\hline Projeler gerçekleştirilebilmeli ve yeni projeler oluşturulmalı & 2 & 1.6 \\
\hline Toplam & 124 & 100.0 \\
\hline
\end{tabular}

\section{SONUÇ}

Araştırma kapsamında 84 kooperatif yöneticisi anket yapılmıştır. Yönetim çoğunluğu erkeklerden oluşmakta ve kadınların azınlıkta olduğu görülmektedir. Antalya ilinde bir kadın yönetici aynı zamanda kooperatif başkanı görevini yürütmektedir. Kadın başkanın seçilmesinde en önemli faktör olarak güven duygusu ve kooperatif imkânlarının amaç dışı kullanılmayacağı inancından kaynaklandığ belirtilmiştir. Kadın yöneticilerin artması ile birlikte toplumun diğer yarsının da kooperatifçiliğin gelişmesine katkı sağlayacak ve sürdürülebilir bir örgütlenme olasılığ ${ }_{1}$ artacaktır.

Yöneticilerin öğrenim durumu bölgeler arasında farkl1lık göstermektedir. Sürdürülebilir bir örgütlenme için yöneticilerin öğrenim düzeyinin yüksek olması, uzlaşma ve demokrasi kültürünün gelişmesine katkı sağlayacaktır.

Kooperatifleşmenin beklenen etkiyi oluşturması üst birliklerin kurulması ile sağlanacaktır. Yerel güçlerin birleşerek genel tarım politikaları hakkında yönlendirici olmaları ancak üst birliklerle olabilir. Üst birliklerin etkili olması yerel kooperatifleri sürükleyici etki oluşturacaktır.

Tarımı ikinci meslek olarak yapan kişilerin kooperatiflerde ağırlıklı olarak yönetici oldukları anlaşılmaktadır. Bu durum sektöre farklı açılardan zenginlik katarken diğer taraftan tarım kooperatiflerinin yöneticilerini kendi içerisinden çıkarması gerektiğini göstermektedir. Yöneticilerin asıl mesleklerinin farklı oluşu sürdürülebilir bir örgütlenme sağlamaktan uzaktır. En ufak bir risk veya daha yüksek avantajlar sağlamaları durumunda bu yöneticiler asıl mesleklerine döneceklerdir.

Yöneticilik deneyimin yanında dinamizm eklenmesi durumunda sürdürülebilir örgütlenme gündeme gelecektir. Nitekim çok eski deneyimlere ve geniş mal varlığına sahip bazı kooperatifler atıl vaziyette beklemektedir. Hiçbir üretim ve ticari faaliyet yapmamaktadır. $\mathrm{Bu}$ durum kooperatifçiliğin gelişmesini olumsuz etkilemektedir. Eğitim yanında farklı ülkeleri görmek yöneticilere daha farklı fikirleri geliştirmelerinde katkı sağlayacaktır.

Yurt dişındaki başarılı kooperatiflerin görülmesi ve yerinde incelenmesi Türkiye'deki kooperatifçiliğin başarısına katkı sağlayacaktır. Bu konuda yapılacak yönlendirici ve teşvik edici çalışmalar yararlı olacaktır. Yurt içindeki örnek uygulamaların görülmesi ve karşılıklı deneyimlerin paylaşılması başarıyı artıracaktır.

Yöneticilerin sürekli aynı kişilerden oluşması kooperatifin paylaşımcı ve demokratik yapısına ters gelmektedir. Kooperatifçilik deneyimi yüksek olan kooperatiflerde bile kooperatifçilik ilkeleri, Kooperatif Başkanları tarafından bilinmediği anlaşılmaktadır. Bu ilkelerin bilinmemesinin bir nedeni de bu ilkelerin uygulamasının yapılmamasıdır. Kooperatifçiliğin diğer ekonomik birleşmelerden farklılı̆ı̆ını ortaya koyan bu ilkelerin çeșitli iletişim araçları ile tanıtımına ihtiyaç vardır. Örneğin kooperatifin yönetim binalarına bu ilkeler yazılı olarak asılabilir. Bu ilkelerin bilinmesi ve uygulanması sürdürülebilir örgütlenmenin temel koşuludur.

Kooperatiflerin çeşitli ekonomik ve politik etkiler altında kalmaları özerklik ve bağımsızlık ilkesinin bilinirliği azaltmaktadır. Kooperatiflerin bağımsız ve özerk olması gerektiği bilinci oluşmamaktadır.

Serbest giriş ilkesinin uygulanmasında özellikle eski ve mal varlığı fazla olan kooperatiflerde sorunlar bulunmaktadır. Yeni ortakların kooperatife girmesi bir şekilde engellenmektedir. lkelerin uygulanmasında keyfilikler söz konusudur. Bu durum kooperatifçiliğin yaygınlaşmasına engeldir.

Kooperatif genel kurullarında kararlar alınarak risturnlar yatırıma kaydırılıyor. Ancak kooperatifçiliğin temel ilkelerinden birisi 
işletilmemmiş oluyor. Kooperatifleri diğer ortaklıklardan ayıran temel bir ilkenin uygulanması konusunda mevzuat değiştirilmeli ve risturn ödemesi yapılmalardır. $\mathrm{Bu}$ şekilde ortakların kooperatife bağlılığı artacaktır. Üreticilere neden kooperatife ortak olmaları gerektiği açıklanırken, eğer ristrun veriliyor ise iyi bir gerekçe oluşturacaktır.

Sonuç olarak incelenen kooperatiflerde kooperatifçilik ilkeleri uygulama düzeyi düşüktür. Kooperatifçilik genel ilkeler dişında bir şekilde bir araya gelmiş kişilerden oluşan bir topluluk olarak algılanmaktadır. $\mathrm{Bu}$ durum kooperatifçiliğin sürdürülebilirliğini olumsuz etkilemektedir. lkelerin uygulanması ve ilkeleri uygulayan kooperatiflere teşvikler verilmelidir.

Kooperatif yöneticileri kendi kooperatiflerini 3.8 ile orta düzeyin biraz üzerinde başarılı bulmaktadır.

Yönetimde bulundukları kooperatifi oldukça başarılı bulurlarken, bunu aksine Türkiye geneli için olumsuz bir bakışa sahiptirler. Kooperatifler fonksiyonları (girdi tedariki- ürün pazarlaması) açısından daha aktif hale gelmesi durumunda daha başarılı olacaklar ve sürdürülebilir bir örgütlenme sağlanmış olacaktır. Özellikle girdi tedariki ve ürün pazarlamasında kooperatifçilik ilkeleri doğrultusunda kooperatiflerin faaliyetlerini geliştirmeleri gereklidir.

Açık uçlu sorulan sorunun yanıtında kooperatifçiliğin mevcut olan birçok sorununa yönelik öneriler verildiği görülmektedir. Karar vericilerin sorunlar ve çözümüne yönelik önerileri takip etmesi ve değerlendirmesi yararlı olacaktır.

Kooperatif yöneticilerinin özellikleri belirlenmiş ve kooperatif fonksiyonlarına bakışları değerlendirilmiştir. Kooperatifçilik deneyimi yüksek olan kooperatif yöneticileri kooperatif ilkelerini bilmemekte ve önemli bir kısmı ise uygulanmamaktadır. Kooperatifler bu ilkeleri uygulamamaları durumunda kooperatiften çok çeşitli amaçları olan bir birlikteliğe dönüşmektedir. Örneğin politik ve siyasi amaçlar veya ticari amaçlar gündeme gelmektedir. Bu durumlara engel olmanın yolu kooperatifi kooperatif gibi yönetmektir.

Başarılı ve sürdürülebilir bir kooperatifleşme için; kooperatif yöneticileri özverili bir şekilde çalışması gerekmektedir. Köydeki hiçbir kimse dışlanmadan ortak yapmak için uğraşılmalıdır. Siyaset kesinlikle kooperatifin içine girmemelidir. Kooperatifler bağ $\mathrm{l}_{1}$ bulundukları resmi kurumlarla ve üniversiteler ile işbirliği yapmalıdır. Kooperatifler ortaklarının da yararlanacağı devlet destekli projeler yapmalıdır. Kooperatif ortakları ve belde halkı kooperatifi kendi malı gibi sahip çıkmalıdır. Tarım il müdürlüğü bazı resmi işlemlerini kooperatifler aracilığıyla yürütmelidir. Kooperatiflere veteriner ve ziraat mühendisi çalıştırması durumunda ilaç satma ve bulundurma yetkisi verilmelidir. $\mathrm{Bu}$ şekilde davranılması durumunda tarımsal kooperatifler yerel kalkınmaya ve ülke kalkınmasına önemli katkılar sağlayacaktır.

\section{KAYNAKLAR}

Acar, ., Yıldırım, ., 2000. Mandıra şleten Dönerdere Tarımsal Kalkınma Kooperatifine Ortak şletmelerin Ekonomik Analizi, Yüzüncü Y1l Üniv., Ziraat Fak.,Tarım Bilimleri Derg., 10(1):61-70.

Anonim, 2009. Türkiye Kooperatifçilik Kurumu Kayıtları, www.koopkur.org.tr.

Anonim, 2013. Türkiye Kooperatifçilik Kurumu Kayitları. http://www.kopkur.org.tr.

Anonim, 2015. Türkiye Kooperatifçilik Stratejisi ve Eylem Planı (2012-2016). Gümrük ve Ticaret Bakanlığ1 Kooperatifçilik Genel Müdürlüğü, Ankara. Erişim Tarihi: 10.02.2015

Cook, M.,L., 1994. The Role of Management Behavior in Agricultural Cooperatives. Journal of Agricultural Cooperation, 1994:42-58.

Dedeoğlu, M., Yıldırım, ., 2006. Emek Tarımsal Kalkınma Kooperatifine Ortak şletmelerin Ekonomik Analizi, Yüzüncü Yil Üniv., Ziraat Fak., Tarım Bilimleri Derg., 16(1): 39-48.

Karlı, B., Çelik, Y., 2003. Gap Alanındaki Tarım Kooperatifleri ve Diğer Çiftçi Örgütlerinin Bölge Kalkınmasındaki Etkinliği. TEAE Yayın No:97, Ankara, 109s.

Miran, B., 2002. Temel statistik. Ege Üniversitesi Basımevi, zmir, s: 288.

Newbold, P., 1995. Statistics for Business and Economics, Prentice-Hall International, New Jersey, pp:867.

Özdemir, G., 2005. Cooperative-Shareholder Relations in Agricultural Cooperatives in Turkey. Journal Of Asian Economics 16: 315-325.

Özüdoğru, H., 2004. KÖY-KOOP Kırklareli Birliği'nin Ekonomik Analizi ve Yöneticilerin Kooperatif şletmelerinin Başarısına Etkilerinin Değerlendirilmesi. TEPGE, Yayın No:120, 172s.

Serinikli, N., nan, .H., 2007. Edirne Köy Kalkınma Kooperatifleri Birliğinin Ekonomik Analizi. Tekirdağ Ziraat Fak., Derg., 4 (3): 237-248.

Ünal, V., Güçlüsoy, H., Franquesa, R. 2009. A Comparative Study of Success and Failure of Fishery Cooperatives in the Aegean,Turkey. J. Appl. Ichthyol. (2009), 1-7.

Ünal, V., Yercan, M., 2006. Türkiye'de Su Ürünleri Kooperatifleri ve Balıkçılar çin Önemi. E.Ü. Su Ürünleri Derg., 23 (1-2):221-227.

Yercan, M., 1996. zmir Yöresinde Seçilmiş Bazı Tarımsal Amaçlı Kooperatiflerde Kaynak Kullanımı ve Kooperatif şletmelerde Etkinliğin Ölçülmesi Üzerine Bir Araştırma. Ege Üniv., Fen Bil. Enstitüsü Tarım Ekonomisi ABD. Doktora Tezi, zmir.

Yildırım, ., Acar, ., 1999. Süt ve Mamullerinin Değerlendirilmesi ve Pazarlanmasında Tarımsal Kalkınma Kooperatiflerinin Rolü: Van Dönerdere Tarımsal Kalkınma Kooperatifi Örneği. Uluslararası Hayvancılık'99 Kongresi, 21-24 Eylül zmir, 533-540. 